\title{
INHIBITION OF SURGICALLY INDUCED MIOSIS WITH NEPAFENAC
}

\author{
Rabbia Mirza, Imran Basit, Sumayya Khan, Zahid Ullah*, Muhammad Shahid, Muhammad Awais \\ Armed Forces Institute of Ophthalmology/National University of Medical Sciences (NUMS) Rawalpindi Pakistan, *Combined Military Hospital Bannu/National \\ University of Medical Sciences (NUMS) Pakistan
}

\section{ABSTRACT}

Objective: To assess the efficacy of prophylactic administration of $0.1 \%$ nepafenac in the maintenance of trans-operative mydriasis following cataract surgery.

Study Design: Comparative prospective study.

Place and Duration of Study: Armed Forces Institute of Ophthalmology, Rawalpindi, from Oct 2018 to Mar 2019.

Methodology: A total of 70 patients ndergoing cataract surgery phacoemulsification were randomly placed in either the control group or the nepafenac group. Nepafenac eye drops were administered as one drop 8 hourly, 3 days before surgery. Control group didn't receive any medication preoperatively Mydriasis was measured trans-operatively before surgery, after aspiration of the cortex, and then at the end of surgery. Patients of both groups received tobradex 2 weeks post-surgery.

Results: Post-surgery statistically significant (0.001) difference was observed in the mean pupil size between the nepafenac group $(7.88 \pm 0.49)$ and the control group $(6.57 \pm 0.92 \mathrm{~mm})$.

Conclusion: Use of nepafenac prophylactically was very effective in maintenance of trans-operative mydriasis in cataract surgery.

Keywords: Cataract surgery, Miosis, Nepafenac, Prophylactic, Trans-operative mydriasis.

This is an Open Access article distributed under the terms of the Creative Commons Attribution License (https://creativecommons.org/licenses/by-nc/4.0/), which permits unrestricted use, distribution, and reproduction in any medium, provided the original work is properly cited.

\section{INTRODUCTION}

Phacoemulsification, because of the best visual results with intraocular lens (IOL) implantation, is currently the best surgical procedure in cataract surgery ${ }^{1,2}$. Even though there is improvement in IOL material and surgical techniques have greatly advanced in the last decade, there is always the risk of inadvertent trauma to eyes during surgery. Such trauma results in the activation and release of inflammatory mediators including prostaglandins (PGs), cyclooxygenase-1 (COX-1) and COX-2 enzymes ${ }^{4}$. The release of these inflammatory mediators results in ocular symptoms and signs such as pain, inflammation, miosis, posterior synechiae, posterior capsular opacity, changes in intraocular pressure (IOP) and glaucoma ${ }^{5}$. Surgical trauma results in release of PGs which results in miosis of iris. Transoperative complications are greatly reduced, and adequate mydriasis maintained when topical NSAIDS are used to inhibit the release of $\mathrm{PGs}^{6}$.

Two groups of drugs are chiefly used to inhibit trans-operative miosis and control postoperative inflammation. These are non-steroidal anti-inflammatory drugs (NSAIDs) and topical corticosteroids. NSAIDS directly inhibit the COX enzymes whereas steroids act at the level of phospholipase A2 resulting in inhibition of PG release ${ }^{6-8}$. Using both groups of drugs

Correspondence: Dr Rabbia Mirza, Resident Ophthalmology, Armed Forces Institute of Ophthalmology, Rawalpindi Pakistan

Received: 01 Oct 2019; revised received: 03 Nov 2019; accepted: 04 Nov 2019 simultaneously provide a synergistic effect in inhibiting transoperative miosis and controlling intraocular inflammation?.

Topical ophthalmic suspension consisting of $0.1 \%$ nepafenac (Nevanac, Novartis) is very effective in inhibiting miosis as well as in pain relief and post-surgery inflammation ${ }^{10}$. The purpose of this study was to evaluate inhibition of trans-operative miosis by using $0.1 \%$ nepafenac prophylactically.

\section{METHODOLOGY}

It was prospective comparative study conducted in Armed Forces Institute of Ophthalmology, on patients undergoing phacoemulsification cataract surgery, After approved by the Hospital Ethics Review Committee. A total of 70 patients who met the inclusion/exclusion criteria and undergoing cataract surgery phacoemulsification for senile or/and metabolic cataract were included in the study. They were randomly placed in either the control group or the nepafenac group irrespective of the race or gender.

Uncomplicated cataracts were included in the study whereas the exclusion criteria included pregnancy, breastfeeding, history of ocular trauma or surgery, history of infectious eye disease or any prior ocular inflammation, dry eye, and history of any allergy or hypersensitivity to NSAIDS, steroids or any other component of the drug which is to be used in the study. Patients using PG analogs, NSAIDs or steroids within 4 weeks prior to surgerywere also excluded 
from the study. Patients with uncontrolled hypertension, diabetes mellitus (DM), proliferative diabetic retinopathy or macular degeneration/edema, chorioretinopathy and pre-operative mydriasis of $<6 \mathrm{~mm}$ were excluded from the study.

Medical history including review of concurrent diseases and medications along with ophthalmic examination was carried out for all seventy patients before surgery. The ophthalmic examination included visual acuity test, slit lamp examination, tonometry for measuring IOP and fundus examination. Topical 1\% tropicamide along with $5 \%$ phenylephrine using as one drop every 15 minutes (total of 3 doses) were used in combination in both groups. In the nepafenac group, 4 doses of $0.1 \%$ Nepafenac were administered as one drop every 15 minutes one hour before surgery. All patients underwent cataract surgery by phacoemulsification and IOL implantation under either topical or retrobulbar anesthesia. The identity of both groups of patients was concealed from the surgeons.

Small standardized incision technique was use for the phacoemulsification in all patients. Nasal and temporal corneal incisions were made followed by capsulorhexis. Post phacoemulsification, implantation of foldable IOL in the capsular bag was carried out. The incisions were left open without sutures. The horizontal and vertical pupillary diameters were measured in $\mathrm{mm}$ post-surgery with the help of compass under the microscope. It was then followed by cortex aspiration.

Post-surgery all the patients received one drop of tobradex 6 hourly daily for 10 days. Only the nepafenac group was given one drop of nepafenac 8 hourly daily for 3 days pre-surgery and one drop every 15 minutes one hour before surgery. Post-surgery all patients were assessed at day $1^{\text {st }}, 2^{\text {nd }}$ and $4^{\text {th }}$ week. At each visit, visual acuity, slit lamp examination and fundoscopy were carried out.

SPSS-19 and Microsoft excel were used for compilation of data. All the data was described in terms of mean values and proportions for both control and nepafenac groups. Student's t-test was used for comparative analysis. For determination of relative risk and association of qualitative variables Fisher exact test was used. For establishing statistical significance $p$ value of $\leq 0.05$ was used.

\section{RESULTS}

A total of 70 patients were undergoing cataract surgery phacoemulsification were randomly placed in either the control group or the nepafenac group. Thirty five patients included in each group. Clinical and demographic features of both groups were described in table-I. The mean age of patients was $59.35 \pm 9.6$ years, ranging from $39-88$ years. Out of $55.7 \%$ of the patient were male $(n=39)$. The 4 -week follow up period was completed by all the patients and none showed any treatment related adverse effect. No patient had $>1 \pm$ inflammatory cells at the end of first post-operative week.

Table-II showed trans-operative maintenance of mydriasis in both groups at different stages of surgery. Preoperatively both the groups had comparable horizontal pupillary diameter $(8.55 \mathrm{~mm}$ in nepafenac group and 8.24 in the control group) with $p$-value of 0.144 . Post-surgery there was statistically significant difference between the two groups with $p$-value $<0.001$. The total comparative reduction in the size of pupils from the start till end of surgery was also statistically significant. The difference in the nepafenac group was 0.67 $\pm 0.46 \mathrm{~mm}$ whereas in the control group it was $1.67 \pm$ 0.95 . There was $7.82 \%$ loss of mydriasis in the nepafenac group as compared to $20.26 \%$ in the control group. In the control group 21 patients had post-surgery reduction in pupil size of $>1.5 \mathrm{~mm}$ whereas in the nepafenac group only 4 patients had reduction greater than $1.5 \mathrm{~mm}(p<0.001)$.

Table-I: Demographic and clinical data (pre-operatively).

\begin{tabular}{|c|c|c|c|}
\hline \multirow[b]{2}{*}{ Parameter } & \multicolumn{2}{|c|}{ Group } & \multirow[b]{2}{*}{$\begin{array}{c}p \text { - } \\
\text { valve }\end{array}$} \\
\hline & $\begin{array}{l}\text { Control } \\
(\mathrm{n}=35)\end{array}$ & $\begin{array}{c}\text { Nepafenac } \\
(n=35)\end{array}$ & \\
\hline \multicolumn{3}{|l|}{ Age in years } & 0.625 \\
\hline Mean \pm SD & $59.9 \pm 10.8$ & $58.8 \pm 9.5$ & \\
\hline Range & 39 to 82 & 39 to 88 & \\
\hline \multicolumn{3}{|l|}{ Gender, n (\%) } & 0.651 \\
\hline Male & $20(57.1)$ & $19(54.3)$ & \\
\hline Female & $15(42.9)$ & $16(45.7)$ & \\
\hline \multicolumn{3}{|l|}{ Eye, n (\%) } & 0.788 \\
\hline Right eye & $16(45.7)$ & $17(48.5)$ & \\
\hline Left eye & $19(54.3)$ & $18(51.5)$ & \\
\hline \multicolumn{4}{|c|}{ Ocular and Systemic Pathology } \\
\hline Diabetes Mellitus n (\%) & 8 & 6 & 0.592 \\
\hline Hypertension $\mathrm{n}(\%)$ & 8 & 11 & 0.489 \\
\hline Heart disease $\mathrm{n}(\%)$ & 4 & 3 & 0.684 \\
\hline
\end{tabular}

Table-III showing the relative risk of decreasing pupillary size by $>1.5 \mathrm{~mm}$ trans-operatively is 4.9 times greater as compared to the nepafenac group.

\section{DISCUSSION}

Nepafenac is prodrug and is hydrolyzed to Amfenac in the intraocular tissues. Amfenac is its active form and is a powerful inhibitor of COX-1 and COX-2 
Table-II: Trans-surgical mean horizontal pupillary diameter.

\begin{tabular}{|c|c|c|c|}
\hline \multirow{2}{*}{$\begin{array}{l}\text { Stages of } \\
\text { Surgery }\end{array}$} & \multicolumn{2}{|c|}{ Group } & \multirow[b]{2}{*}{$\begin{array}{c}p- \\
\text { value }\end{array}$} \\
\hline & $\begin{array}{l}\text { Control } \\
(\mathrm{mm})\end{array}$ & $\begin{array}{l}\text { Nepafenac } \\
\text { (mm) }\end{array}$ & \\
\hline Before surgery & $8.24 \pm 0.59$ & $8.55 \pm 0.75$ & 0.144 \\
\hline $\begin{array}{l}\text { Following cortex } \\
\text { aspiration }\end{array}$ & $7.18 \pm 0.89$ & $8.10 \pm 0.76$ & $<0.001$ \\
\hline $\begin{array}{l}\text { Conclusion of } \\
\text { surgery }\end{array}$ & $6.57 \pm 0.93$ & $7.88 \pm 0.49$ & $<0.001$ \\
\hline $\begin{array}{l}\text { Total loss of } \\
\text { mydriasis }\end{array}$ & $1.67 \pm 0.95$ & $0.67 \pm 0.46$ & $<0.001$ \\
\hline Percent total loss & $20.26 \%$ & $7.82 \%$ & $<0.001$ \\
\hline \multicolumn{4}{|c|}{ Table-III: Post-surgery decrease in pupil diameter. } \\
\hline & \multicolumn{2}{|c|}{ Groups } & \multirow{2}{*}{$\begin{array}{c}p- \\
\text { value }\end{array}$} \\
\hline & Control & Nepafenac & \\
\hline Loss $\geq 1.5 \mathrm{~mm} \mathrm{n} \mathrm{( \% )}$ & $21(60)$ & $4(11)$ & $<0.001$ \\
\hline
\end{tabular}

enzymes. Nepafenac has excellent permeability and bioavailability in the ocular tissues. Nepafenac is a target specific NSAID due to its speedy bioactivation in ocular tissues. As a result, it inhibits PG synthesis in the posterior and anterior segments of the eye $\mathrm{e}^{11,12}$. During surgery there is trauma to the ocular tissue. This trauma leads to phospholipase A2 activation as well as the release of platelet-activating factors and arachidonic acid metabolites. Arachidonic acid, through cyclooxygenase (COX) pathway, forms prostaglandins (PGs) and through lipoxygenase pathway results in the production of leukotrienes (LTs). Endogenous PGs result in different ocular effects. These include conjunctival hyperemia, post-operative inflammation and miosis as well as increased blood-ocular barrier permeability and changes in intra ocular pressure $^{8}$.

Miosis during surgery makes cataract surgery difficult and there is increase the risk of trauma during surgery. It may also increase the risk of postoperative inflammation of the eye and rupture of posterior capsule. It has been reported that with $>6 \mathrm{~mm}$ of mydriasis, the risk of posterior capsule rupture was reduced by half. This clearly shows that maintaining adequate pupil dilatation is vitalin ensuring smooth cataract removal ${ }^{9}$.

Prostaglandins play a crucial role during eye trauma including cataract surgery which stimulates the inflammatory cascade. The release of a great number of inflammatory mediators like prostaglandins, COX-1 and COX-2 enzymes, causes ocular signs and symptoms such as inflammation, edema, pain, miosis, posterior capsular opacity, changes in intraocular pressure (IOP) and glaucoma ${ }^{10}$. These PGs and their release can be inhibited with topical NSAIDs. Their inhibition results in inhibition of miosis and therefor, adequate trans-surgical mydriasis can be maintained. Consequently, trans-operative complications are minimized. Nepafenac $0.1 \%$ is an NSAID and is aprodrug. Inside the intraocular tissues, nepafenac is hydrolyzed to amfenac which is a potent inhibitor of COX- 1 and COX${ }^{211}$. As a result, PG synthesis is blocked. It has excellent bioavailability and ocular tissue penetration. Numerous studies have established that NSAIDS such as nepafenac are effective in maintenance of trans-operative mydriasis $^{12}$.

This study has demonstrated that the use of $0.1 \%$ topical nepafenac was effective as an inhibitor of miosis during cataract surgery. During the entire surgical procedure, we found that the nepafenac group had consistent tendency towards much greater dm unlike the control group. In control group there was a gradual failure in maintenance of mydriasis during different stages of surgery. Mydriatic effects of topical flurbiprofen and prednisolone have been analyzed by Shaikh et al. They found no statistical difference between the two drugs ${ }^{13}$. On the other hand, there were different studies which have reported greater mydriasis when flurbiprofen was used as compared to prednisolone 14,15 . Similarly, it was reported that administration of ketorolac preoperatively for 3 days has better results in maintaining mydriasis as compared to 1 day and 1 hour regimen preoperatively ${ }^{16-18}$.

In this study, we administered nepafenac 3 days before surgery and 4 times one hour before surgery. Moreover, though this study has shown significant results in maintenance of mydriasis during phacoemulsification future studies comparing nepafenac with other NSAIDs and its effects on macular edema in the long run are warranted.

\section{CONCLUSIONS}

The prophylactic use of nepafenac $0.1 \%$ topical eye drops was found effective and safe in maintaining trans-operative mydriasis during cataract surgery. It is the first known clinical study for evaluation of the effect of $0.1 \%$ nepafenac on pupil size during cataract surgery.

\section{CONFLICT OF INTEREST}

The study does not have any conflict of interest to be declared by any author.

\section{REFERENCES}

1. Linebarger EJ, Hardten DR, Shah GK. Phacoemulsification and modern cataract surgery. Surv Ophthalmol 1999; 44(2): 123-47. 
2. Gogate PM, Kulkarni SR, Krishnaiah S. Safety and efficacy of phacoemulsification compared with manual small-incision cataract surgery by a randomized controlled clinical trial: six-week results. Ophthalmol 2005; 112(5): 869-74.

3. Riaz Y, Mehta JS, Wormald R. Surgical interventions for age-related cataract. Cochrane Database Syst Rev 2006; 4(1): CD001323.

4. Mohammadpour M, Jafarinasab MR, Javadi MA. Outcomes of acute postoperative inflammation after cataract surgery. Eur J Ophthalmol 2007; 17(1): 20-28.

5. Yuksel B, Karti O, Kusbeci T. Topical nepafenac for prevention of post cataract surgery macular edema in diabetic patients: Patient selection and perspectives. Clin Ophthalmol 2017; 11(2): 2183-90.

6. Muhtaseb M, Kalhoro A, Ionides A. A system for preoperative stratification of cataract patients according to risk of intra-operative complications: a prospective analysis of 1441 cases. Br J Ophthalmol 2014; 88(2): 1242-46.

7. El-Harazi SM, Ruiz RS, Feldman RM. A randomized doublemasked trial comparing ketorolac tromethamine $0.5 \%$, diclofenac sodium $0.1 \%$, and prednisolone acetate $1 \%$ in reducing post-phacoemulsification flare and cells. Ophthalmic Surg Laser 1998; 29(1): 539-44.

8. Guclu H, PelitliGurlu V. Comparison of topical nepafenac $0.1 \%$ with intravitreal dexamethasone implant for the treatment of Irvine-Gass syndrome. Int J Ophthalmol 2019; 12(2): 258-67.

9. Mokbel T, Saleh S, Abdelkader M, El-Khouly SE, AbouSamra W, Mamdouh M. Functional and anatomical evaluation of the effect of nepafenac in prevention of macular edema after phacoemulsification in diabetic patients. Int J Ophthalmol 2019; 12(3): 387-92.

10. Lane SS. Nepafenac: a unique nonsteroidal prodrug. Int Ophthal- mol Clin 2016; 46(1): 13-20.

11. Walters $T$, Raizman M, Ernest P. In vivo pharmacokinetics and in vitro pharmacodynamics of nepafenac, amfenac, ketorolac, and bromfenac. J Cataract Refract Surg 2007; 33(1): 1539-45.

12. Mokbel T, Saleh S, Abdelkader M, El-Khouly SE, AbouSamra W, Mamdouh M. Functional and anatomical evaluation of the effect of nepafenac in prevention of macular edema after phacoemulsification in diabetic patients. Int J Ophthalmol 2019; 12(3): 387-92.

13. Shaikh MY, Mars JS, Heaven CJ. Prednisolone and flurbiprofen drops to maintain mydriasis during phacoemulsification cataract surgery. J Cataract Refract Surg 2003; 29(2): 2372-77.

14. Thaller VT, Kulshrestha MK, Bell K. The effect of pre-operative topical flurbiprofen or diclofenac on pupil dilatation. Eye 2010; 14(1): 642-45.

15. Srinivasan R, Madhavaranga. Topical ketorolac tromethamine $0.5 \%$ versus diclofenac sodium $0.1 \%$ to inhibit miosis during cataract surgery. J Cataract Refract Surg 2012; 28(2): 517-20.

16. Zhao X, Xia S, Wang E, Chen Y. Comparison of the efficacy and patients' tolerability of Nepafenac and Ketorolac in the treatment of ocular inflammation following cataract surgery: A metaanalysis of randomized controlled trials. PLoS One 2017; 12(3): e0173254.

17. Hovanesian J, Holland E. Tolerability and toxicity of topically applied nepafenac $0.3 \%$ compared with generic ketorolac $0.5 \%$. J Cataract Refract Surg 2019; 45(2): 174-80.

18. Almeida DR, Khan Z, Xing L, Bakar SN, Rahim K, Urton T, ElDefrawy SR. Prophylactic nepafenac and ketorolac versus placebo in preventing postoperative macular edema after uneventful phacoemulsification. J Cataract Refract Surg 2012; 38(9): 1537-43. 